\title{
Risk factors associated with the frequency of antibodies against Babesia bovis and Babesia bigemina in cattle in southern Mozambique ${ }^{1}$
}

\author{
António A.M. Tembue ${ }^{2,3}$, Fábio J.M. Silva ${ }^{2}$, Jenevaldo B. Silva², Tiago M. Santos², \\ Huarrisson A. Santos ${ }^{2}$, Cleber O. Soares ${ }^{4}$ and Adivaldo H. Fonseca ${ }^{2 *}$
}

\begin{abstract}
Tembue A.A.M., Silva F.J.M., Silva J.B., Santos T.M., Santos H.A., Soares C.O. \& Fonseca A.H. 2011. Risk factors associated with the frequency of antibodies against Babesia bovis and Babesia bigemina in cattle in southern Mozambique. Pesquisa Veterinária Brasileira 31(8):663-666. Laboratório de Doenças Parasitárias, Departamento de Parasitologia Animal, Universidade Federal Rural de Rio de Janeiro, Seropédica, RJ 23890000, Brazil. E-mail: adivaldo@ufrrj.br

The study aimed to evaluate the risk factors associated with the frequency of IgG antibodies against Babesia bovis and B. bigemina in cattle in southern Mozambique. Eight hundred and nine serum samples were collected from cattle in three provinces namely Maputo, Gaza and Inhambane, and tested by indirect enzyme-linked immunosorbent assay (i-ELISA) to assess the humoral immune response towards B. bovis and B. bigemina. The chi-square test at $5 \%$ significance was used to determine whether there was an association between gender, age and geographic origin of seropositive animals. The overall prevalence was $78.8 \%(548 / 695)$ for $B$. bovis and $76.0 \%$ (528/695) for B. bigemina. The origin of the animals showed a significant association $(\mathrm{p}<0.05)$ with seropositivity to both agents, while gender and age was not associated ( $p>0.05)$. Maputo province had the highest rate of positive animals, with $93.7 \%(118 / 126)$ for B. bovis and 97.6\% (123/126) for B. bigemina. In Gaza province 77.3\% (321/415) of the animals were positive for $B$. bovis and $67.5 \%(280 / 415)$ for B. bigemina, while in the province of Inhambane the levels of seropositivity were $70.8 \%(109 / 154)$ and $81.2 \%(125 / 154)$ for $B$. bovis and B. bigemina respectively. In the present study, the frequency of cattle positive for $B$. bovis and B. bigemina was shown to increase among older age groups, suggesting that infection and re-infection persisted even after the primary infection. Thus, this region is considered to be in a state of enzootic stability with regards to B. bovis and B. bigemina.
\end{abstract}

INDEX TERMS: Babesia bovis, Babesia bigemina, cattle, babesiosis, epidemiology, Mozambique.

RESUMO.- [Fatores de risco associados à frequência de anticorpos contra Babesia bovis e B. bigemina em bovinos da Região Sul de Moçambique.] Foram avaliados os fatores de risco associados a frequência de anticorpos da classe IgG contra Babesia bovis e B. bigemina em bovinos da re-

\footnotetext{
${ }^{1}$ Received on January 17, 2010

Accepted for publication on April 11, 2011.

Part of the doctoral thesis of first author.

${ }^{2}$ Curso de Pós-Graduação em Ciências Veterinárias, Instituto de Veterinária, Universidade Federal Rural de Rio de Janeiro (UFRRJ), Seropédica, RJ 23890-000, Brazil. *Corresponding author: adivaldo@ufrrj.br

${ }^{3}$ Laboratório Central de Veterinária (LCV), Direcção de Ciências Animais (DCA), Instituto de Investigação Agrária de Moçambique (IIAM), Avenida de Moçambique Km1.5, Caixa Postal 1922, Maputo, Moçambique. E-mail: am.tembue@gmail.com

${ }^{4}$ Embrapa Gado de Corte, Área de Sanidade Animal, BR 262 Km 4, Caixa Postal 154, Campo Grande, MS 79002-970, Brazil.
}

gião sul de Moçambique. Oitocentos e nove amostras de soros foram coletadas de bovinos em três províncias nomeadamente Maputo, Gaza e Inhambane e testados por ensaio de imunoadsorção enzimático indireto (i-ELISA) para avaliar a resposta imune humoral contra B. bovis e B. bigemina. 0 teste de Qui-quadrado a $5 \%$ de significância foi utilizado para verificar a associação entre as variáveis sexo, faixa etária e origem geográfica com a soropositividade dos animais. A prevalência geral foi de 78,8\% (548/695) para B. bovis e $76,0 \%(528 / 695)$ para B. bigemina. A origem dos animais apresentou associação $(\mathrm{p}<0,05)$ com a soropositividade a ambos os agentes, enquanto variável sexo não apresentou associação $(p>0,05)$. A província de Maputo apresentou a maior taxa de animais positivos, com 93,7\% (118/126) para B. bovis e $97,6 \%(123 / 126)$ para B. bigemina. Na província de Gaza a soropositividade foi de 67,5\% (280/415) para $B$. 
bigemina e 77,3\% (321/415) para B. bovis enquanto que na província de Inhambane a positividade foi de $81,2 \%$ (125/ $257)$ e $70,8 \%$ (109/257) para B. bigemina e B. bovis, respectivamente. Na presente pesquisa, a freqüência de bovinos positivos para $B$. bovis e B. bigemina aumentou nas faixas etárias superiores, sugerindo que as infecções e as re-infecções persistem mesmo após primo-infecção. A região estudada apresenta-se na condição de estabilidade enzoótica para os agentes estudados.

TERMOS DE INDEXAÇÃO: Babesia bovis, B. bigemina, bovinos, babesiose, epidemiologia, Moçambique.

\section{INTRODUCTION}

About 902.579 cattle are reared in the southern region of Mozambique, a value equivalent to $53.6 \%$ of the national total, estimated at 1.683.589 animals (Tia, 2008). These animals are prone to infection by Babesia bovis and B. bigemina, which are directly associated with the presence of the ticks Rhipicephalus microplus, $R$. decoloratus, $R$. everts everts and Hyalomma marginatum rufipes (De Matos 2008).

In the mid-1990s the government of Mozambique implemented a livestock restocking program based on the import of cattle from the Republic of South Africa and Zimbabwe (Martins et al 2008). However, this increase in the production of ruminants in the country was not accompanied by improvements in sanitary conditions, what led to the occurrence of different diseases including the following tick-borne conditions: Babesiosis, anaplasmosis, ehrlichiosis and theileriosis. These diseases negatively affected the productive and reproductive efficiency of livestock by causing the death of more than half the animal population (Simuunza et al. 2010).

These pathogens trigger a massive destruction of red blood cells in their hosts, promoting lysis of these cells followed by invasion of other erythrocytes (De Vos et al. 2004). Thus, infections with Babesia spp. in cattle are characterized by fever, anemia, hemoglobinemia, hemoglobinuria, and in many cases, death (Martins et al. 2008).

Babesiosis is responsible for severe damage to the animal and exerts a large economic impact on livestock production in tropical regions (Jonsson et al. 2008). The dynamics of infection by Babesia spp. depend on several factors, such as size and composition of the population of ticks, the transmission capacity of the vector and the susceptibility of the cattle, which can vary with breed, age and physiological conditions (Bock et al. 1997, Jonsson et al. 2008) as well as the agro-ecological and edaphic-climatic conditions of each geographical region.

The seroepidemiological study of bovine babesiosis in a given geographical area is important, because it may reveal the potential for outbreaks of this disease. Serological diagnostic methods are essential tools for assessing the prevalence and the immune status of animals as well as generating important information that can be used to control the tick vectors (Mahoney \& Ross 1972, Mahoney 1975). The indirect enzyme-linked immunosorbent assay (i-ELISA) is the test that has given better results due to its high level of sensitivity and specificity (Madruga et al. 2001).
The objective of the current investigation was to examine possible correlation between gender, age and geographic region as risk factors associated with the prevalence of IgG antibodies against B. bovis and B. bigemina in cattle from the provinces of Maputo, Gaza and Inhambane, southern Mozambique.

\section{MATERIALS AND METHODS}

This study was carried out in the southern region of Mozambique, which occupies an area of $167.641 \mathrm{~km}^{2}$, at a latitude of $25^{\circ} 58^{\prime \prime}$ south and a longitude of $32^{\circ} 35^{\prime}$ east, with an average altitude of 120 meters, characterized by a tropical, humid climate (Inam 2010). The current evaluated cattle (Bos indicus) and their crossbreed from herds in the provinces of Maputo, Gaza and Inhambane. These provinces acoount for $53.6 \%$ of the national cattle population, equivalent to 902.579 head, with 179.028 in inhambane, 569.404 in Gaza and 154.147 in Maputo respectively (Tia 2008).

A total of 809 serum samples were collected. The samples were derived from 110 rural smallholders with 4 located in Maputo, 78 in Gaza and the remaining 28 in Inhambane. The study was carried out between January to March 2010, and cattle owners participated voluntarily in this study. The inference was performed by nonprobabilistic sampling, obeying the proportional stratification of each province studied. Thus, in each rural smallholder community samples were taken in order to represent $10 \%$ of the total herd.

In order to assess the association between rates of IgG antibodies against Babesia bovis and B. bigemina and the variables of age, gender and origin, animals were categorized as follows: Age ( $\geq 6$ to $\leq 12$ months, and $>12$ to $\leq 36$ months and $>36$ months), sex (male and female) and origin (Maputo, Gaza and Inhambane).

Blood samples were collected aseptically by coccygeal venipuncture in $10 \mathrm{~mL}$ tubes vacutainer. Subsequently, the samples from the province of Maputo were transported under refrigeration using ice packs to the Central Veterinary Laboratory (CVL), Directorate of Animal Science (DCA) at the Institute for Agrarian Research of Mozambique (IIAM), samples from Gaza were processed at the Regional Veterinary Laboratory of South-Gaza/ IIAM while the samples from Inhambane were processed at the Provincial Livestock Services Laboratory of Inhambane. In all cases, samples were submitted to centrifugation at $2.000 \mathrm{xg}$ for 10 minutes in order to separate the clot and obtain serum. About $1 \mathrm{~mL}$ of serum was separated into polypropylene microtubes of $1.5 \mathrm{ml}$ and placed in a freezer at $-20^{\circ} \mathrm{C}$ until the execution of serological tests. Serological analyses were performed at the Laboratory of Parasitic Disease, Department of Epidemiology and Public Health, Federal Rural University of Rio de Janeiro (UFRRJ) and at the Laboratory of the National Center for Research in Agrobiology, Brazilian Agricultural Research Corporation (Embrapa Agrobiologia). Serum samples were tested by i-ELISA for the detection of IgG antibodies against $B$. bovis and B. bigemina using 96 well microplate 96 (Corning, Costar $\AA 3590$, USA). The microplates were previously sensitized with crude antigen of B. bovis and B. bigemina kindly supplied by National Research Center for Beef Cattle of the Brazilian Agricultural Research Corporation (Embrapa Gado de Corte), and processed according to the technique described by Madruga et al. (2001). Plates were read using a microplate spectrophotometer (Labsystems IEMS Reader MF) at a wavelength of $492 \mathrm{hm}$. The cutoff for i-ELISA was established with the confidence level of $99.5 \%$ Frey et al. (1998).

The frequency of seropositive cattle of all categories (age, gender and origin were calculated and differences between groups assessed by using Chi-square $\left(\chi^{2}\right)$ at $5 \%$ of significance using the statistical software BioStat $®$, version 4.0 (Ayres et al. 2000). 
Table 1. Prevalence of antibodies against Babesia bigemina and Babesia bovis in cattle detected by indirect enzymelinked immunosorbent reaction and associated factors in Southern of Moçambique

\begin{tabular}{|c|c|c|c|c|c|c|c|}
\hline \multirow[t]{2}{*}{ Factor } & \multirow[t]{2}{*}{$\mathrm{N}$} & \multicolumn{2}{|c|}{$\begin{array}{c}\text { Babesia } \\
\text { bigemina }\end{array}$} & \multicolumn{2}{|c|}{$\begin{array}{c}\text { Babesia } \\
\text { bovis }\end{array}$} & \multicolumn{2}{|c|}{$\begin{array}{c}\text { B. bigemina e } \\
\text { B. bovis }\end{array}$} \\
\hline & & $\mathrm{n}$ & $\%$ & $\mathrm{n}$ & $\%$ & $\mathrm{n}$ & $\%$ \\
\hline Prevalence & 695 & 528 & 76.0 & 548 & 78.8 & 535 & 77.0 \\
\hline \multicolumn{8}{|l|}{ Age (months) } \\
\hline$\geq 6$ the $\leq 12$ & 118 & 95 & $80.5^{\mathrm{a}}$ & 97 & $82.2^{\mathrm{a}}$ & 85 & $72.0^{\mathrm{a}}$ \\
\hline$>12$ the $\leq 36$ & 115 & 90 & $78.3^{\mathrm{a}}$ & 90 & $78.3^{\mathrm{a}}$ & 89 & $77.4^{\mathrm{a}}$ \\
\hline$>36$ & 462 & 343 & $74.2^{\mathrm{a}}$ & 361 & $78.1^{\mathrm{a}}$ & 316 & $68.4^{\mathrm{a}}$ \\
\hline \multicolumn{8}{|l|}{ Sex } \\
\hline Females & 438 & 334 & $76.3^{\mathrm{a}}$ & 345 & $78.8^{\mathrm{a}}$ & 326 & $74.4^{\mathrm{a}}$ \\
\hline Males & 257 & 194 & $75.5^{\mathrm{a}}$ & 203 & $79.0^{\mathrm{a}}$ & 194 & $75.5^{\mathrm{a}}$ \\
\hline \multicolumn{8}{|l|}{ Province } \\
\hline Maputo & 126 & 123 & $97.6^{\mathrm{A}}$ & 118 & $93.7^{\mathrm{A}}$ & 106 & $84.1^{\mathrm{A}}$ \\
\hline Inhambane & 154 & 125 & $81.2^{\mathrm{B}}$ & 109 & $70.8^{\mathrm{B}}$ & 120 & $77.9^{\mathrm{B}}$ \\
\hline Gaza & 415 & 280 & $67.5^{C}$ & 321 & $77.3^{\mathrm{B}}$ & 275 & $66.3^{C}$ \\
\hline
\end{tabular}

$\mathrm{N}=$ numbers of animals collected, $\mathrm{n}=$ numbers of samples positive to Babesia bigemina and B. bovis. Values in the column followed by same letters do not have statistically significant difference between groups or factors studied (a) by test $\chi^{2}(p>0.05)$. Values with statistically significant differences between provinces are indicated by different capital letters (A, B and $\mathbf{C})$ by test $\chi^{2}(\mathrm{p}<0.05)$.

\section{RESULTS}

Prevalence values of animals seropositive for Babesia bovis and B. bigemina in three provinces of southern Mozambique (Maputo, Gaza and Inhambane) are provided in (Table 1). The results show that the overall prevalences of antibodies against B. bigemina and B. bovis were $76.0 \%(528 / 695)$ and $78.8 \%$ (548/695) respectively.

The percentages of prevalence for Babesia spp. determine on the basis of age, gender and geographic region are represented in (Table 1). There was no association ( $p>0.05)$ between gender and age seropositivity for either B. bovis or B. bigemina, on the other hand, while the factors of origin of the animals showed a significant association $(\mathrm{p}<0.05)$ with seropositivity to both agents studied.

Analysis of data for B. bovis revealed a prevalence of $82.2 \%$ (97/118), 78.3\% (90/115) and 78,1\% (361/462) among animals of age $\geq 6$ to $\leq 12$ months, $>12$ to $\leq 36$ and over 36 months, respectively, (Table 1). For B. bigemina the seroprevalence was $80.5 \%$ (95/118), 78.3\% (90/115) and 74.2\% (343/462) for the three age groups examined. However, no significant differences were observed among groups aged greater than 12 months $p>0.05$ (Table 1 ).

When evaluating the demographic region as a risk factor associated with seropositivity, we found the statistically significant differences between provinces showed the highest frequency $(\mathrm{p}<0.05)$ of seropositive cattle for both agents, whereas in the Maputo, Inhambane and Gaza the frequency was $93.7 \%$ (118/126), 70.8\% (109/154) and 77.3\% (321/ 415) for B. bovis, and $97.6 \%$ (123/126), 81.2\% (125/154) and $67.5 \%(280 / 415)$ for $B$. bigemina, respectivelly. The prevalence rate showed that cattle in the province of Maputo were more likely to be seropositive for B. bigemina and $B$. bovis than animals coming from the provinces of Inhambane and Gaza $(\mathrm{p}<0.05)$.

\section{DISCUSSION}

The results of this study concur with those of previous other conducted in countries from tropical regions (Jonsson et al. 2008). In regions in eastern and southern Africa, studies indicate that bovine babesiosis presents seropositivity ranging from 19.5 to $94.0 \%$ of the cattle (Dreyer et al. 1998, Mbata et al. 2002, Mtshali et al. 2004, Martins et al. 2008). In South Africa, these studies showed that the prevalence of antibodies against Babesia bigemina ranged from 62.4 to $94.0 \%$, and in the case of $B$. bovis the frequency was $19.5 \%$. In Kenya the prevalence of Babesia spp. in cattle was 37.1\%, according to the study of Okuthe \& Buyu (2006).

In southern Mozambique is raised predominantly beef cattle, consisting mostly of Indian origin breed (Bos indicus) and their crossbreed, which are considered to be naturally resistant to parasitism by ticks (Mahoney 1975). However, the prevalence in this region for B. bovis and B. bigemina was found to be $78.8 \%(548 / 695)$ and $76.0 \%(528 / 695)$ respectively, suggesting great potential for transmission of these agents by ticks prevalent in that area. According to Mahoney \& Ross (1972), prevalence rates equal to or greater than $75.0 \%$ classify the area as one of enzootic stability. Furthermore, it indicates that the cattle are infected before completing the first year of life, and are constantly re-infected. In this way, the animals maintain their immune system active against the agents in question.

In present study the seroprevalence detected was higher than $75 \%$, characterizing the southern region of Mozambique as an area of enzootic stability for bovine babesiosis. In a situation of enzootic stability, calves are infected during the early months of life and are protected by colostral antibodies (passive immunity), thus enabling the development of active immunity without the manifestion of clinical disease. However, it should be noted that a study examining calves with age below six months (Jonsson et al. 2008), it was concluded that under conditions of high tick infestation high morbidity and mortality can occur even in during the period when protection was being conferred by colostral antibodies (Jonsson et al. 2008).

The association of gender with the seropositivity of the cattle to B. bigemina and B. bovis was not significantly different ( $p>0.05$ ), confirming the findings of previous studies (Soares et al. 2000, Trindade et al. 2010).

The statistically significant differences observed in positive cattle from the same provinces studied in relation to the prevalence of antibodies against B. bovis and B. bigemina, may be due to variation in the rate of infection by ticks and, subsequently, a variation in the rate of cattle inoculation by the infected ticks. The animals are exposed to more risk conditions associated with outbreaks of babesiosis infection by $B$. bovis and B. bigemina in cattle was not homogeneous among the same province.

In the current study, the seropositivity for B. bigemina $77.3 \%$ (321/415) in Gaza province was higher when compared with the level obtained for B. bovis $67.5 \%$ (280/415). In this province, there exists a higher percentage of Bos indicus species, which are considered to more resistant to tick infestation (Madruga et al. 1984), and with which higher larval mortality is observed (Gonzáles 1974). 
These data demonstrate that the disease has a varied distribution within the provinces. A previous study of natural infection in bovines of the beef cattle breed from the region the Tete province revealed a seropositivity level of $39.1 \%$ for B. bovis (Alfredo et al. 2005). It is possible that the observed differences between the earlier study and our data may have resulted from a seasonal increase in the tick population, in a lack of control of such an increase, or from the subsequent introduction of susceptible animals, derived from South Africa and Zimbabwe, during the livestock restocking program.

During the blood collection process, the presence of ticks was observed on all the farms, despite the frequent use of tick control drugs containing pyrethroids and avermectins, as well as a high prevalence of babesiosis. Host and environment are factors that affect the prevalence of babesiosis in a particular region (Mahoney \& Ross 1972).

Information in relation to the levels of antibodies against $B$. bovis and B. bigemina in cattle in the study areas will provide insights to managers of national livestock to improve their knowledge of the immunological status of herds, and may contribute towards the development of future interventions and management strategies in animal health. In this context, knowing the prevalence of agents in each province, one can develop geo-referenced maps of regions of stability and instability to provide better control of enzootic disease in the country.

The results of this study corroborate the findings from studies conducted in the countries of southern and eastern Africa, where the variation of infection by B. bigemina and $B$. bovis depends on factors such as the prevalence of vectors and measures related to their control, but is independent of gender.

We conclude that the southern region of Mozambique should be considered as an area of enzootic stability for both B. bovis and B. bigemina. Moreover, this region offers risk for transmission of babesiosis to susceptible animals coming from areas of enzootic instability. Therefore, the use of appropriate preventive measures is needed, especially with regard to the effective control of ticks. In these circumstances, further studies would be justified in order to monitor the herds for purpose of identifying factors that may pose risks to the current epidemiological status of the region.

Acknowledgements.- To Prof. Dr. Carlos L. Massard, Flábio R. Araújo and to Embrapa Agrobiologia for their laboratory facilities. To the National Council of Scientific and Technological Development (CNPq) and the Ministry of Science and Technology of the Republic of Mozambique (MCT$\mathrm{Mz}$ ) for financial support and the opportunity granted.

\section{REFERENCES}

Alfredo A.A.N., Jonsson N.N., Finch T.M. \& Neves L. 2005. Serological survey of Babesia bovis and Anaplasma marginale in cattle in Tete province, Mozambique. Trop. Anim. Health Prod. 37(2):21-131.

Ayres M., Ayres Jr M., Ayres D.L. \& Santos A.A.S. 2000. BioEstat 4.0 - Aplicações Estatísticas nas Áreas das Ciências Biológicas e Médicas. Editora Sociedade Civil Mamirauá, Belém. 272p.

Bock R.E., De Vos A.J., Kingston T.G. \& McLellan D.J. 1997. Effect of breed of cattle on innate resistance to infection with Babesia bovis, B. bigemina and Anaplasma marginale. Aust. Vet. J. 75(5):337-340.

Bock R., Jackson L., De Vos A. \& Jorgensen W. 2004. Babesiosis of cattle. Parasitol. 129(Suppl.):247-269.
De Matos C.A. 2008. Species composition and geographic distribution of ticks infesting cattle, goats and dogs in Maputo province, Mozambique. MSc. Dissertation in Veterinary Science, Faculty of Veterinary Science, University of Pretoria. 130p. <http://upetd.up.ac.za/thesis/available/etd02202009-0124/unrestricted/dissertation.pdf> Accessed Nov. 14, 2010.

De Vos A.J., De Waal D.T. \& Jackson L.A. 2004. Bovine babesiosis, p.406424. In: Coetzer J.A.W. \& Tustin R.C. (Eds), Infectious Diseases of Livestock with Special Reference to Southern Africa. Vol.1. Oxford University Press, Cape Town.

Dreyer K., Foure L.J. \& Kok D.J. 1998. Epidemiology of tick-borne diseases of cattle in Botshabelo and Thaba Nchu in the Free State Province. Onderstepoort J. Vet. Res. 65(4):285-289.

Frey A., Canzio J.D. \& Zurakowski D. 1998. A statistically defined endpoint titer determination method for immunoassays. J. Immunol. Methods 221(1/2):35-41.

Gonzáles J.C. 1974. 0 carrapato do boi: vida, resistência e controle. Mestre Lou, São Paulo. 101p.

Inam.2010. Instituto Nacional de Meteorologia de Moçambique. Disponível em: http://www.inam.gov.mz. Acesso em: 24 de novembro de 2010

Jonsson N.N., Bock R.E. \& Jorgensen W.K. 2008. Productivity and health effects of anaplasmosis and babesiosis on Bos indicus cattle and their crosses, and the effects of differing intensity of tick control in Australia. Vet. Parasitol. 155(1/2):1-9.

Levy M.G., Clabaugh G. \& Ristic M. 1982. Age resistence in bovine babesiosis: Role of blood factors in resistance to Babesia bovis. Infect. Immun. 37(3):1127-1131.

Madruga R.C., Marques A.P.C., Araujo F.R., Miguita M., Carvalho C.M.E. \& Umaki A.C.S. 2001. Evaluation of an ELISA for detection of antibodies to Babesia bigemina in cattle and its application in an epidemiological survey in Brazil, Pesq. Vet. Bras. 21(2):72-76.

Madruga C.R., Aycardi E., Kesller R.M., Schenk M.A.M., Figueredo G.R. \& Curvo J.B.E. 1984. Níveis de anticorpos anti-Babesia bigemina e Babesia bovis, em bezerros da raça Nelore, Ibagé e cruzamentos de Nelore. Pesq. Agropec. Bras. 19:1163-1168.

Martins T.M., Neves L., Pedro O.C., Fafetine J.M., Do Rosário V.E. \& Domingos A. 2010. Molecular detection of Babesia spp. and other haemoparasitic infections of cattle in Maputo province, Mozambique. Parasitol. 137(6): 939-946.

Martins T.M., Pedro O.C., Caldeira R.A., Do Rosário V.E., Neves L. \& Domingos A. 2008. Detection of bovine babesiosis in Mozambique by a novel seminested hot-start PCR method. Vet. Parasitol. 153(3/4):225-230.

Mahoney D.F. \& Ross D.R. 1972. Epizootiological factors in the control of bovine babesiosis. Aust. Vet. J. 48(5):292-298.

Mahoney D.F. 1975.The diagnosis of babesiosis in Australia, p.49-62. In: Wells E.A. (Ed.), Workshop on Hemoparasites (Anaplasmosis and Babesiosis). CIAT, Cali, Colombia.

Mbati P.A., Hlatshwayo M., Mtshali M.S., Mogaswane K.R., Waal T.D. \& Dipeolu 0.0. 2002. Ticks and tick-borne diseases of livestock belonging to resource-poor farmers in eastern Free State of South Africa. Exp. Appl. Acarol. 28(1/4):217-224.

Mtshali M.S., De Waal D.T. \& Mbati P.A. 2004. A sero-epidemiological survey of blood parasites in cattle in the north-eastern Free State, South Africa. Onderstepoort J. Vet. Res. 71(1):67-75.

Okuthe O.S. \& Buyu G.E. 2006. Prevalence and incidence of tick-borne diseases in smallholder farming systems in the Western-Kenia highlands. Vet. Parasitol. 141(3-4):307-312.

Simuunza M., Weir W., Courcier E., Tait A. \& Shiels B. 2010. Epidemiological analysis of tick-borne diseases in Zambia. Vet. Parasitol. 175(3/ 4):331-342.

Soares C.O., Souza J.C.P., Madruga C.R., Madureira R.C., Massard C.L. \& Fonseca A.H. 2000. Soroprevalência de Babesia bovis em bovinos na mesorregião Norte Fluminense. Pesq. Vet. Bras. 20(2):75-79.

TIA 2008. Trabalho de Inquérito Agrícola. Ministério da Agricultura de Moçambique, Maputo.

Trindade H.I., Silva G.R.A., Teixeira M.C.A., Sousa M.G., Machado R.Z., Freitas F.L.C. \& Almeida K.S. 2010. Detection of antibodies against Babesia bovis and Babesia bigemina in calves from the region of Araguaína, State of Tocantins, Brazil. Rev. Bras. Parasitol. Vet. 19(3):169-173. 